J. Lake Sci.(湖泊科学), 2017, 29(3): 637-645

DOI 10. 18307/2017. 0312

(c) 2017 by Journal of Lake Sciences

\title{
淮河流域春季浮游植物群落结构特征及其水质评价”
}

\author{
朱为菊 ${ }^{1}$, 庞婉婷 ${ }^{2}$, 尤庆敏 ${ }^{2}$, 王全喜 ${ }^{2 * *}$ \\ ( 1 : 中国热带农业科学院热带生物技术研究所, 海口 571101) \\ (2: 上海师范大学生命与环境科学学院, 上海 200234)
}

\begin{abstract}
摘 要: 浮游植物是内陆水体生态系统的主要初级生产者, 其群落结构能反映水体的水质状况. 为了全面了解淮河流域 内浮游植物群落结构及水质现状, 于 2013 年 5 月在流域内设置 217 个样点采集浮游植物样品. 共鉴定浮游植物 244 种 (含变种和变型), 隶属于 8 门 104 属, 绿藻门和硅藻门的种类最丰富. 浮游植物生物量为 $3.93 \mathrm{mg} / \mathrm{L}$, 在 $0.04 \sim 83.62 \mathrm{mg} / \mathrm{L}$ 之间变动,生物量组成主要为甲藻门、硅藻门和隐藻门. 浮游植物种类数和生物量在河流的中游较高, 溪流以及下游人江 人海河道较低. 浮游植物优势种主要为隐藻门的啮蚀隐藻 (Cryptomonas erosa) 、尖尾蓝隐藻 ( Chroomonas acuta), 硅藻门的 梅尼小环藻 (Cyclotella meneghiniana), 甲藻门的角甲藻 (Ceratium hirundinella), 其相对生物量均大于 5\%. 淮河流域浮游植 物多样性指数较低, 流域内多数样点处于中-重污染状态.
\end{abstract}

关键词: 淮河流域; 浮游植物; 水质评价; 多样性指数

\section{Phytoplankton community structure and the evaluation of water quality in spring, Huaihe River Basin}

\author{
ZHU Weiju ${ }^{1}$, PANG Wanting ${ }^{2}$, YOU Qingmin ${ }^{2} \&$ WANG Quanxi ${ }^{2 * *}$ \\ (1: Institute of Tropical Bioscience and Biotechnology, Chinese Academy of Tropical Agricultural Science, Haikou 571101, P. \\ R. China) \\ (2: College of Life and Environmental Sciences, Shanghai Normal University, Shanghai 200234, P.R.China)
}

Abstract: Phytoplankton is a key primary producer in inland water ecosystem because its community structure can indicate the water quality. To understand the phytoplankton community structure and the water quality state in Huaihe River Basin, 217 sites were set and the phytoplankton samples were collected in the basin in May 2013. The 244 taxa of phytoplankton ( species and variety species) belonging to 104 genera 8 phyla were identified, of which the most abundant phyla is Chlorophyta, followed by Bacillariophyta. The average phytoplankton biomass was $3.93 \mathrm{mg} / \mathrm{L}$, ranging from 0.04 to $83.62 \mathrm{mg} / \mathrm{L}$, while Dinophyta, Bacillariophyta and Cryptophyta were major groups upon the biomass. The richness and biomass of phytoplankton was low in the small streams and the pathway to the sea, but high in the middle of the river. The main dominant species were Cryptomonas erosa, Chroomonas acuta, Cyclotella meneghiniana and Ceratium hirundinella, whose relative biomass were higher than $5 \%$. The phytoplankton diversity index was low and most sites were in a medium-heavy pollution state.

Keywords: Huaihe River Basin; phytoplankton; water quality evaluation; diversity index

浮游植物是江河湖库等水体生态系统的主要初级生产者, 对水域生态系统的物质循环、能量流动及维 持水域生态系统平衡方面都起着非常重要的作用. 由于浮游植物群落结构对水体环境变化非常灵敏,其群 落结构组成及其多样性等指标能准确反映水体的水质状况, 弥补水体理化指标在水质评价上的不足 ${ }^{[1]}$,利 用浮游植物评价水质状况已受到国内外学者的关注 ${ }^{[2-4]}$. 国外有关河流中浮游植物群落的研究, 可以追溯到 上世纪初 Kofoid ${ }^{[5]}$ 对美国伊利诺伊河流 (Illinois River) 的浮游植物研究. 进人 1930 s 后, 研究工作主要集中

* 国家水体污染控制与治理科技重大专项 (2012ZX07501002-003) 和上海市教委项目 (14YZ069) 联合资助. $2016-$ 04-25 收稿; 2016-09-19 收修改稿. 朱为菊(1980 ), 女,博士, 助理研究员; E-mail: gdzxzwj@ 163.com.

** 通信作者;E-mail:wangqx@ shnu.edu.cn. 
在美国中南部的密西西比河 (Mississippi River) 的上游、美国中东部的马里兰州波多马克河 (Potomac River $)^{[6-7]}$ 等. 此后, 欧美等国家的众多学者纷纷开展关于河流中浮游植物群落的研究工作, 并利用浮游植物特 征来评价河流生态系统状况 ${ }^{[8-11]}$.

我国学者自 1950s 起开展了局部河流的浮游植物群落结构的调查研究工作 ${ }^{[12]}$, 多数集中在黑龙江流域 和黄河流域等. 近年来相关报道显示, 利用浮游植物多样性指数可以反映河流的水质状况及富营养化状 态 ${ }^{[13-15]}$. 进人 21 世纪以后, 由于我国水体污染及水环境问题日益严峻, 各大流域纷纷开展相关的河流生态 调查 ${ }^{[16-17]}$, 以期能全面了解河流生态系统的现状, 但是尚缺乏从大流域的尺度了解浮游植物群落结构及其 对水质状况评价的研究.

淮河流域位于我国东部,介于长江流域和黄河流域之间, 流域内自北向南为暖温带向亚热带的气候过 渡带, 由于流域内高密度的人口及不均衡的产业结构, 导致水质污染严重, 生物多样性下降, 河流生态系统 受到极大破坏 ${ }^{[18]}$, 流域内生态环境问题日益突出. 而有关流域内浮游植物与水质评价的工作,多集中在部 分河段, 如山东省的沂河 ${ }^{[19]}$ 、河南省的颖河 ${ }^{[20]}$, 尚缺乏大尺度的利用浮游植物评价淮河流域水质状况的研 究. 为了能全面了解流域内浮游植物群落结构及水质现状, 本研究于 2013 年 5 月在全流域内设置 217 个样 点, 对浮游植物群落多样性进行调查, 旨在为淮河流域水生生态监测及水生态系统的健康评价提供数据支 持和理论依据,为河流水生态系统健康评估和监测提供科学依据.

\section{1 材料与方法}

\section{1 研究区域概况}

淮河是我国自然地理上一条重要的分界线,西起桐柏山、伏牛山,介于长江流域和黄河流域之间,流域横 跨湖北、河南、安徽、山东、江苏 5 个省份 40 个地(市)、 236 个县(市), 淮河干流全长 $1000 \mathrm{~km}$. 流域面积 $2.7 \times 10^{5}$ $\mathrm{km}^{2}$, 该流域以废黄河为界, 分为两大水系: 淮河水系和沂沭泗水系, 面积分别约为 $1.9 \times 10^{5}$ 和 $8.7 \times 10^{4} \mathrm{~km}^{2}$. 流域 内多年平均降水量为 $875 \mathrm{~mm}$, 其中, 位于河南省和安徽省的淮河水系多年平均降水量为 $911 \mathrm{~mm}$, 沂沭泗水 系为 $788 \mathrm{~mm}$, 降水量在地区上分布不均匀, 总体趋势是南部大、北部小, 沿海大、内陆小, 山丘区域大于平原 区域. 降水量的时间分布也不均匀, $6-8$ 月降水最多, 集中了全年的 $40 \% \sim 65 \%{ }^{[21]}$.

淮河流域内人河的排污量远远大于水环境容量, 导致流域内水污染问题格外突出. 1994 年和 2004 年发 生的震惊中外的淮河水污染事件, 说明了淮河水质进一步恶化; 经过国家 1996-2005 年“九五”计划和“十 五” 计划的水污染综合治理, 水污染恶化的势头在淮河流域得到有效控制, 水环境质量也向较好的方向发 展,但是严峻的水体污染形势仍然存在.

\section{2 采样时间和样点设置}

由于平水期河流的水位、流量等保持在较为平稳的状态, 适合浮游植物的生长. 本研究于 2013 年 5 月 (平水期) 在全流域内设置 217 个样点 (图 1), 开展浮游植物群落结构的调查研究. 在河流的上、中、下游随 机设置样点, 并确保每个支流至少有 3 个样点, 217 个样点涵盖淮河流域的干流和支流河道, 生境类型包括 溪流以及流速缓慢甚至是静止的中等到大型河流, 水体的营养状态从贫营养到富营养.

\section{3 样品的采集和鉴定}

浮游植物定量样品: 用 $1 \mathrm{~L}$ 有机玻璃采水器在河流的断面, 于水面以下 $0.5 \mathrm{~m}$ 处采集水样 $1000 \mathrm{ml}$ 置于 采样瓶中. 按照 $1.5 \%$ 的体积比例加人鲁哥试剂现场固定, 将采集的样品带回实验室静置 $48 \mathrm{~h}$ 后, 利用虹吸 法缓缓吸去上清液, 定容至 $50 \mathrm{ml}$, 并加人 $4 \%$ 甲醛溶液保存 ${ }^{[22]}$.

浮游植物定性样品: 用 $25^{\#}$ 浮游生物网 (网孔直径为 $0.064 \mathrm{~mm}$ ) 在表层至 $0.5 \mathrm{~m}$ 处拖动浮游生物网数次, 待水滤去后打开浮游生物网下面的阀门, 将采集到的浮游植物样品收集至 $50 \mathrm{ml}$ 的标本瓶中, 加人 $4 \%$ 甲醛 溶液现场固定. 并在瓶体贴上标签, 注明采样时间、地点、采集人等基本信息, 带回实验室以待镜检.

浮游植物定性和定量样品用 Nikon 50i 显微镜, 参照文献 $[23]$ 进行鉴定, 定量样品的计数方法依据《淡 水浮游生物研究方法 $\rangle^{[22]}$. 淡水浮游植物的密度近似等同于淡水的密度, 即浮游植物的生物量为浮游植物 的数量乘以各自的平均体积. 细胞的体积测定时依据藻类的体型按照最相似的几何形态测量 ${ }^{[24]}$.

\section{4 数据分析}

利用相对频度 $(F r)$ 反映种的个体在群落中的出现频率, 公式为: 


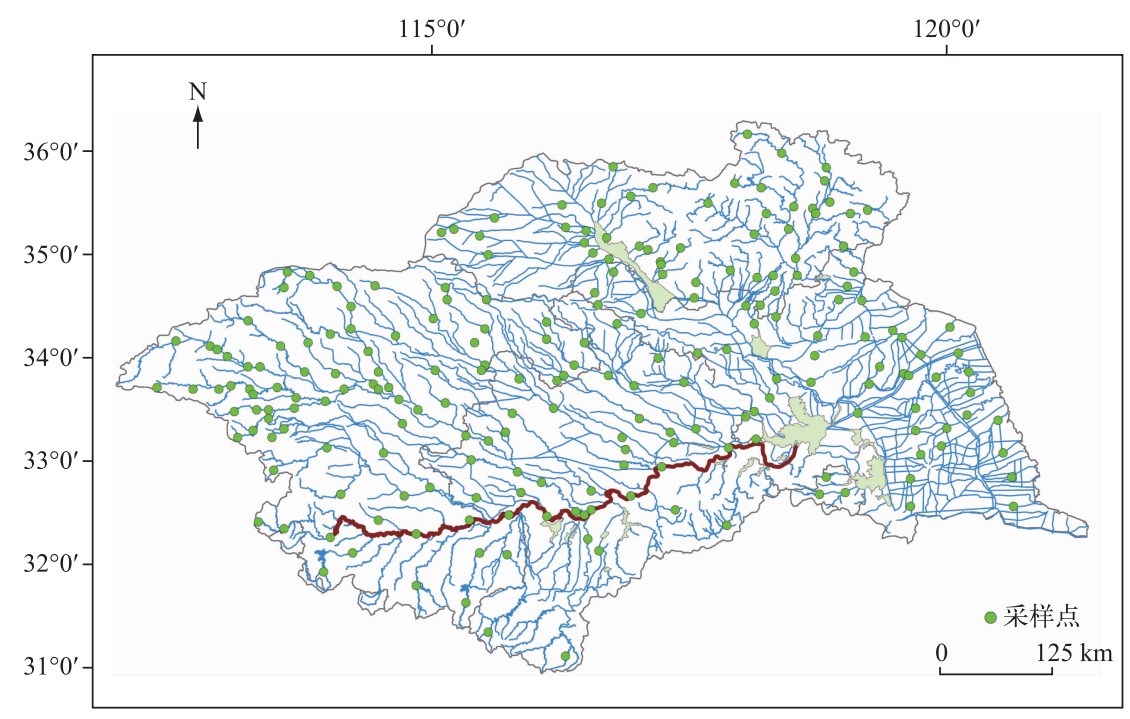

图 1 淮河流域浮游植物采集样点

Fig. 1 Sampling sites of phytoplankton in Huaihe River Basin

$$
F r=f_{i} / F \times 100 \%
$$

式中, $f_{i}$ 为 $i$ 种出现的次数, $F$ 为总的采样点数. $\mathrm{A}$ 级频度为 $1 \% \sim 20 \%$; B 级频度为 $21 \% \sim 40 \%$; 级频度为 $41 \% \sim 60 \%$; D 级频度为 $61 \% \sim 80 \%$; $\mathrm{E}$ 级频度为 $81 \% \sim 100 \%$.

以相对生物量大于 $2 \%$ 定义为浮游植物优势种.

利用 Shannon-Wiener 多样性指数 $\left(H^{\prime}\right)$ 和 Pielou 均匀度指数 $(J)$ 来评价河流的水质状况, 公式分别为:

$$
H^{\prime}=-\sum\left(n_{i} / N\right) \log _{2}\left(n_{i} / N\right)
$$

式中, $N$ 为浮游植物总个体或细胞数; $n_{i}$ 为 $i$ 种的个体或细胞数.

$$
J=H^{\prime} / \ln S
$$

式中, $S$ 为浮游植物总种类数.

使用 SPSS 软件对浮游植物种类数和生物量分布的空间差异进行 $t$ 检验.

\section{2 结果与分析}

\section{1 浮游植物种类组成}

在淮河流域共鉴定出浮游植物 244 种 (含变种和变型), 隶属于 8 门 104 属. 其中绿藻门的种类最丰富, 为 41 属 101 种, 其次为硅藻门 29 属 53 种, 蓝藻门 18 属 39 种, 裸藻门 5 属 36 种, 金藻门 5 属 6 种, 甲藻门 3 属 5 种, 隐藻门 2 属 3 种, 黄藻门 1 属 1 种.

根据浮游植物的出现频度, 其中属于 $\mathrm{E}$ 级频度 ( $>80 \%$ ) 的种类有隐藻门的啮蚀隐藻 (Cryptomonas erosa) 和硅藻门的梅尼小环藻 (Cyclotella meneghiniana); 属于 D 级频度 (61\% 80\%) 的种类有绿藻门的四尾栅藻 (Scenedesmus quadricauda)、隐藻门的尖尾蓝隐藻 (Chroomonas acuta)、硅藻门的隐头舟形藻 (Navicula cryptocephala) 和蓝藻门的阿氏颤藻 (Oscillatoria agardhii).

全流域单个站点的浮游植物种类数在 $4 \sim 60$ 之间波动, 浮游植物种类数的平面分布差异显著 $(P<0.05$, $t=38.34$ ). 位于淮河流域的南部山区以及江苏省的下游人江人海河道 (里下河水系) 的浮游植物种类数较 少, 总体呈现上游和下游较少、中游较多的趋势 (图 2). 


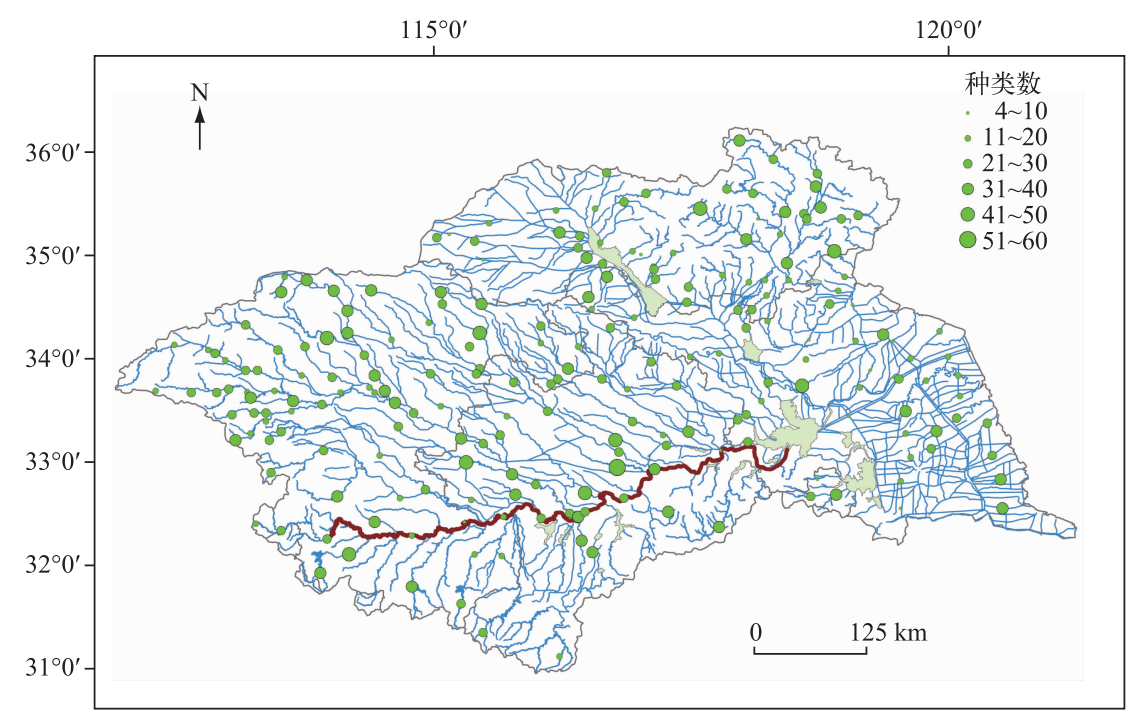

图 2 淮河流域浮游植物种类数分布

Fig.2 Distribution of phytoplankton species number in Huaihe River Basin

表 1 淮河流域浮游植物生物量组成

Tab.1 The composition of phytoplankton biomass in Huaihe River Basin

\begin{tabular}{ccc}
\hline 门类 & 生物量 $/(\mathrm{mg} / \mathrm{L})$ & 相对生物量 $/ \%$ \\
\hline 蓝藻门 & 0.22 & 5.57 \\
金藻门 & 0.18 & 4.62 \\
黄藻门 & 0.0004 & 0.0098 \\
硅藻门 & 0.92 & 23.36 \\
隐藻门 & 0.77 & 19.50 \\
甲藻门 & 1.03 & 26.09 \\
裸藻门 & 0.41 & 10.46 \\
绿藻门 & 0.41 & 10.39 \\
总计 & 3.93 & 100 \\
\hline
\end{tabular}

\section{2 浮游植物生物量}

淮河流域浮游植物总生物量在 $0.04 \sim 83.62 \mathrm{mg} / \mathrm{L}$ 之间 变动, 平均生物量为 $3.93 \mathrm{mg} / \mathrm{L}$. 从浮游植物生物量组成来 看, 以甲藻门、硅藻门和隐藻门为主, 生物量分别为 1.03 、 0.92 和 $0.77 \mathrm{mg} / \mathrm{L}$, 分别占总生物量的 $26.09 \% 、 23.36 \%$ 和 $19.50 \%$ (表 1).

$t$ 检验分析结果显示浮游植物生物量的平面分布差异显 著 $(P<0.05)$. 从浮游植物生物量的分布来看 (图 3), 位于淮 河流域上游河道、南部山区河道以及江苏省的里下河水系中 的浮游植物生物量较低, 总体呈现上游和下游较低、中游较 高的趋势. 从浮游植物群落结构来看, 在上游多数河道中硅 藻门的比例较高, 在中游河道中隐藻门或裸藻门的相对生物 量较高, 在下游河道中蓝藻门、绿藻门的相对生物量较高.

\section{3 浮游植物优势种}

淮河流域浮游植物优势种有 12 种 (表 2), 分别为: 隐藻门的啮蚀隐藻、尖尾蓝隐藻和卵形隐藻, 其相对 生物量分别为 $11.84 \% 、 6.53 \%$ 和 $2.79 \%$; 硅藻门的梅尼小环藻、谷皮菱形藻、颗粒直链藻和肘状针杆藻, 其相 对生物量分别为 $9.03 \% 、 4.04 \% 、 2.31 \%$ 和 $2.13 \%$; 甲藻门的角甲藻, 其相对生物量为 $8.67 \%$; 蓝藻门的伪鱼腥 藻和小席藻, 其相对生物量为 $2.44 \%$ 和 $3.06 \%$; 裸藻门的尖尾裸藻, 其相对生物量为 $2.9 \%$; 绿藻门的球衣藻, 其相对生物量为 $2.62 \%$.

\section{4 浮游植物多样性及其水质评价}

淮河流域浮游植物 Shannon-Wiener 指数在 0.06 3.15 之间波动 (图 4), 平均值为 1.93. 根据 ShannonWiener 多样性指数评价等级 ${ }^{[3]}: 0 \sim 1$ 为重污染; $1 \sim 3$ 为中污染; $>3$ 为轻污染或无污染. 淮河流域 20 个站点 处于重污染状态, 占总样点数的 $9.2 \%, 197$ 个站点处于中污染状态, 占总样点数的 $90.7 \%$, 仅有 1 个样点处于 轻污染状态.

淮河流域浮游植物 Pielou 均匀度指数在 $0.01 \sim 0.49$ 之间波动 (图 5), 平均值为 0.34 . 按照 Pielou 均匀度 指数评价等级 ${ }^{[26]}: 0 \sim 0.3$ 为重污染; $0.3 \sim 0.5$ 为中污染; $0.5 \sim 0.8$ 为轻污染或无污染. 淮河流域 116 个站点处 


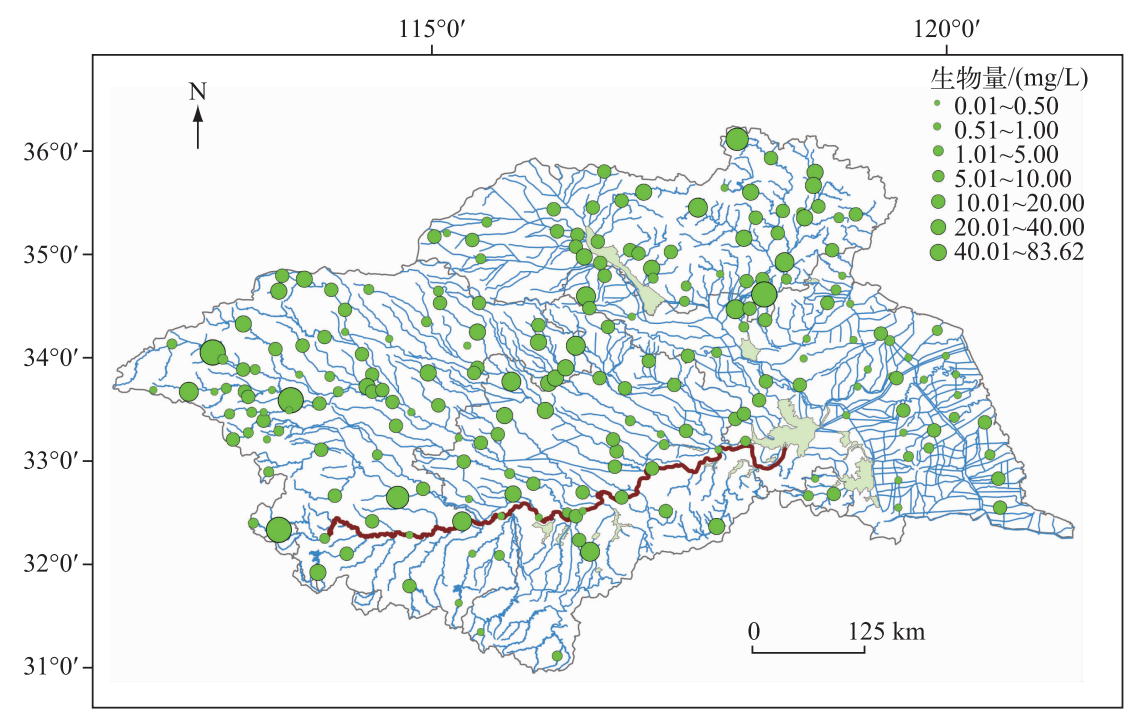

图 3 淮河流域浮游植物生物量分布

Fig. 3 Distribution of phytoplankton biomass in Huaihe River Basin

于重污染状态, 占总样点数的 $53.5 \%, 102$ 个 站点处于中污染状态, 占总样点数的 $47.0 \%$.

\section{3 讨论}

\section{1 淮河流域浮游植物群落结构特征}

淮河流域浮游植物种类组成以绿藻门和 硅藻门的种类为主, 与天然河流浮游植物种 类组成以硅藻门的种类为主有一定的差 异 ${ }^{[25-26]}$. 淮河流域地处黄河流域和长江流域 之间,流域内气候类型为暖温带向亚热带气 候类型过渡, 比较适合藻类的生长. 而本次研 究共鉴定浮游植物种类数 244 种, 这与赣江 流域的浮游植物种类数 312 种相比较少 ${ }^{[27]}$, 而与黄河流域相比较丰富 ${ }^{[28]}$, 与高纬度的新 疆阿勒泰地区额尔齐斯河流域相比较少 ${ }^{[29]}$. 从浮游植物的出现频度来看, 指示水体富营 养状态的梅尼小环藻和啮蚀隐藻分布较广,
表 2 淮河流域浮游植物优势种

Tab.2 The dominant species of phytoplankton in Huaihe River Basin

\begin{tabular}{|c|c|c|}
\hline 门类 & 优势种 & 水质指示状态 ${ }^{[25]}$ \\
\hline \multirow[t]{2}{*}{ 蓝藻门 } & 伪鱼腥藻 ( Pseudanabaena sp.) & $\alpha$-中污 \\
\hline & 小席藻(Phormidum tenus) & $\alpha-\beta$-中污 \\
\hline \multirow[t]{3}{*}{ 隐藻门 } & 尖尾蓝隐藻 ( Cryptomonas acuta) & $\alpha-\beta$-中污 \\
\hline & 卵形隐藻 ( Cryptomonas ovata) & $\alpha$-中污 \\
\hline & 啮蚀隐藻 ( Cryptomonas erosa) & $\alpha-\beta$-中污 \\
\hline \multirow[t]{4}{*}{ 硅藻门 } & 梅尼小环藻 (Cyclotella meneghiniana) & $\alpha-\beta$-中污 \\
\hline & 颗粒直链藻 ( Melosira granulata) & $\alpha-\beta$-中污 \\
\hline & 肘状针杆藻 (Synedra ulna) & $\alpha-\beta$-中污 \\
\hline & 谷皮菱形藻 ( Nitzschia palea) & $\beta$-中污 \\
\hline 甲藻门 & 角甲藻 (Ceratium hirundinella) & $\alpha$-中污 \\
\hline 裸藻门 & 尖尾裸藻 (Euglena oxyuris) & $\beta$-中污 \\
\hline 绿藻门 & 球衣藻 (Chlamydomonas globosa) & $\alpha-\beta$-中污 \\
\hline
\end{tabular}

表明流域内多数河流受到一定程度的污染. 分布广的物种通常被认为具有较宽的生态位, 其利用资源的能 力和多样化程度较高, 竞争能力较强 ${ }^{[30]}$. 物种的分布格局一方面反映物种占有空间资源的多少, 另一方面 反映了物种在生境中的分布状况. 分布广的物种, 占据资源点位多,适应多样化生境资源的能力强. 在淮河流 域隐藻门的尖尾蓝隐藻和啮蚀隐藻、硅藻门的梅尼小环藻的分布极其广泛, 表明这些种类适应环境的能力较 强. 徐春燕等 ${ }^{[30]}$ 对淀山湖浮游植物优势种生态位的研究发现, 尖尾蓝隐藻的生态位宽度较大, 对资源的利用能 力强, 分布范围广; 梅尼小环藻的表面积与体积之比较大, 能快速的吸收水体的营养盐. 在淮河流域有些浮游 植物优势种的分布范围较窄, 如尖尾裸藻、颗粒直链藻等,占据的资源点位相对集中,在下游河段的生物量较 高, 这主要是由于裸藻适合生在浊度高和有机物含量较高的环境中, 下游河道接纳中上游河道的有机物, 适合 裸藻类植物的生长. 角甲藻的分布具有明显的地域性, 在河南段的生物量较高. 尖尾裸藻适合生活在从农田或 


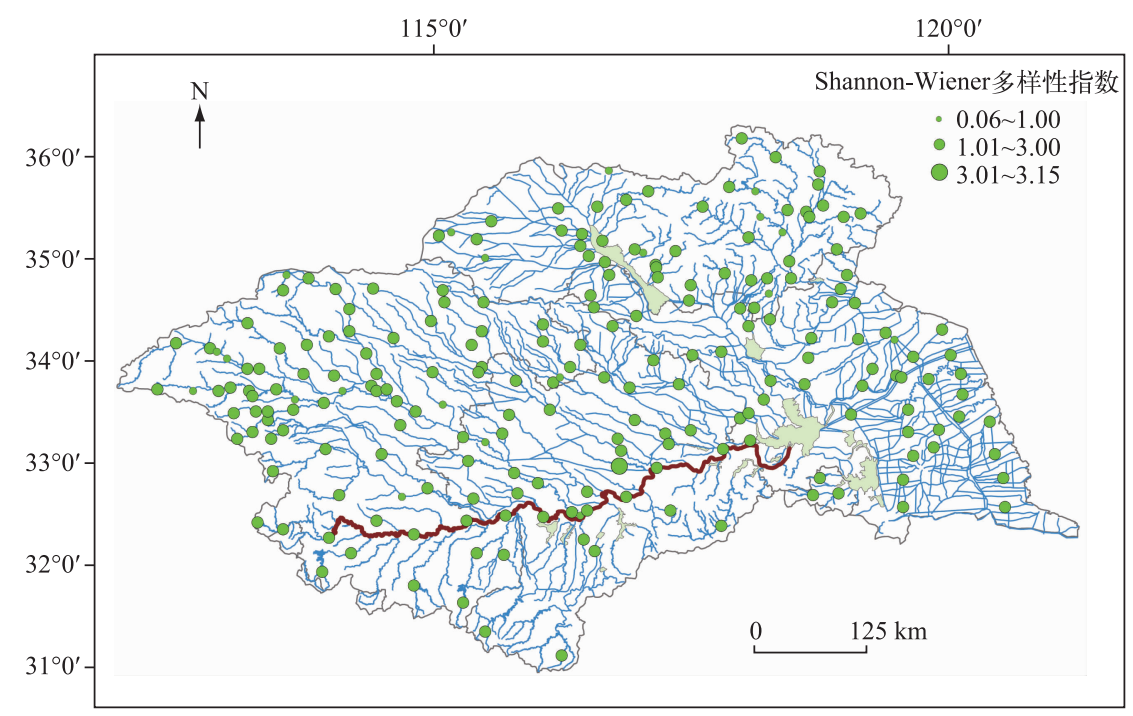

图 4 淮河流域浮游植物 Shannon-Wiener 多样性指数分布

Fig.4 Distribution of phytoplankton Shannon-Wiener diversity index in Huaihe River Basin

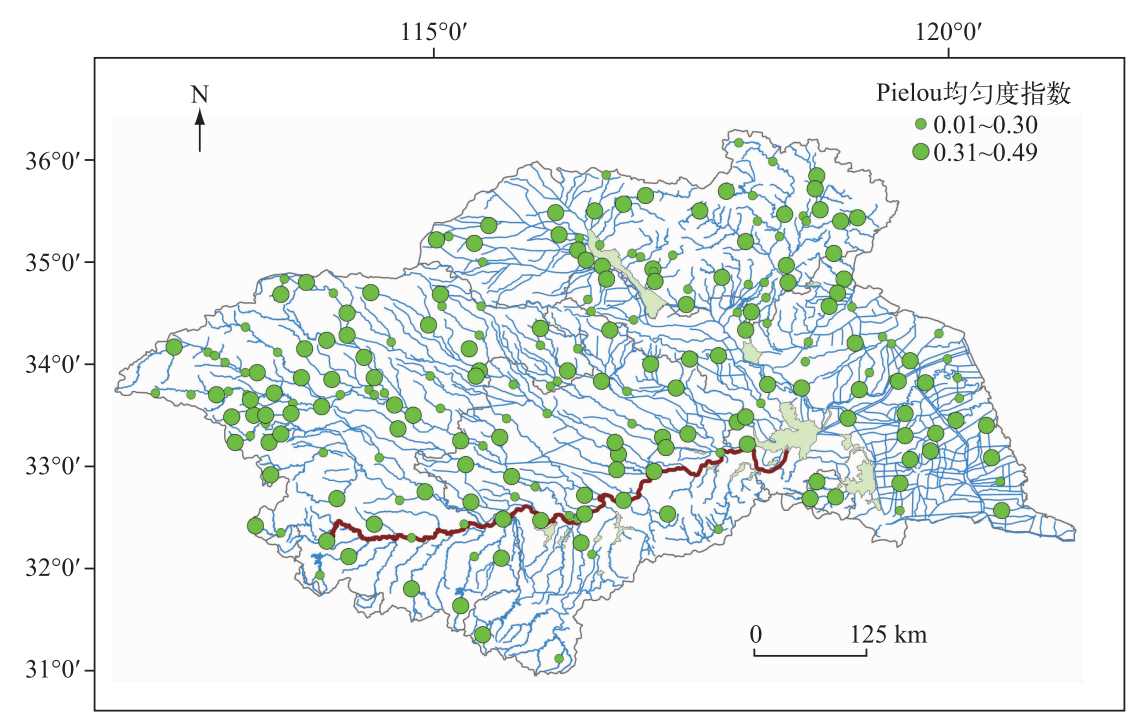

图 5 淮河流域浮游植物 Pielou 均匀度指数分布

Fig.5 Distribution of phytoplankton Pielou evenness index in Huaihe River Basin

污水中获得有机质的池塘或临时形成的水体,这说明淮河流域水体受到一定的农业污染.

淮河流域浮游植物群落结构组成具有一定的独特性, 生物量组成以甲藻门和硅藻门为主. 本次样品采 集时间为 4-5 月, 气温开始升高, 促进了藻类的生长, 尤其是鞭毛藻类如甲藻门和隐藻门的种类, 其借助鞭 毛的游动寻找适合生长的小环境, 从而快速吸收水体的营养盐而生长, 甲藻门的种类体积较大, 因此生物量 贡献较大. 此外, 硅藻门的种类在春末夏初也可以快速生长.

淮河流域浮游植物种类数和生物量在河流上游、南部山区以及位于江苏省的里下河水系较低, 中游河 段较高, 这与吴利等 ${ }^{[31]}$ 对淮河干流浮游动物群落结构的研究结果相一致. 上游河段营养盐浓度较低、流速 较急, 硅藻门的种类能在这样的环境中生长; 而里下河水系主要为人工河道, 受人为干扰较大, 河道透明度 
较低, 光线成为限制藻类生长的主要因子 ${ }^{[32]}$; 中游河段流速变缓, 营养盐适中, 为藻类的生长营造了适宜的 环境, 一些鞭毛藻类 (隐藻门和裸藻门) 在这样的环境中占据优势地位. 此外, 有少部分上游河道以隐藻为 主, 说明这些河流受到了一定的有机污染.

\section{2 淮河流域浮游植物优势种与水质状况}

淮河流域浮游植物优势种以指示水体中-富营养状态的鞭毛藻 (啮蚀隐藻、卵形隐藻、尖尾蓝隐藻、角甲 藻) 和硅藻门的种类 (梅尼小环藻、谷皮菱形藻、颗粒直链藻) 为主. 隐藻在淮河流域分布较广, 且占有较高的 比例, 能耐受低光的环境 ${ }^{[33]}$, 在受到一定有机污染的环境中形成优势种 ${ }^{[26]}$. 根据 Reynolds 浮游植物功能类 群的划分 ${ }^{[34]}$ : 尖尾蓝隐藻属于 $\mathrm{X} 2$, 该类群适合的生境为中营养型到富营养型的浅水水体 ${ }^{[35]}$; 梅尼小环藻属 于 $\mathrm{C}$, 该类群适合生活在富营养型的小中型湖泊,无分层现象; 颗粒直链藻属于 $\mathrm{P}$, 该类群栖息在 $2 \sim 3 \mathrm{~m}$ 的连 续或者半连续的水体混合层, 水体营养指数较高. 这些类群在淮河流域广泛分布, 可能是由于淮河流域大量 闸坝的存在 ${ }^{[36]}$, 使得河流生境向湖泊生境演变, 从而提供了一个适合功能类群 $\mathrm{C}$ 和 $\mathrm{P}$ 生活的环境, 这也说 明了淮河流域水体的富营养化程度较高. 角甲藻属于 $\mathrm{L}_{0}$, 该功能类群的生存范围广, 能在从浅水到深水、从 中等到大型湖泊、从贫营养到富营养的环境生存 ${ }^{[35]}$. 根据况琪军等 ${ }^{[25]}$ 利用藻类水质指示种评价的标准, 淮 河流域浮游植物优势种中有 7 种为 $\alpha-\beta$-中污种类, 显示淮河流域水质状况为中污染.

\section{3 淮河流域浮游植物多样性与水质评价}

一般来讲, 多样性指数越高, 群落结构越稳定, 水质状况也越好. 淮河流域浮游植物多样性指数评价显 示, 除上游河道 (河南段) 和南部山区的样点处于轻污染状态外, 流域内多数样点处于中-重污染状态, 与流 域水环境现状相一致 ${ }^{[37]}$, 说明浮游植物群落多样性指数适用于评价大型流域的水质状况. 此外, 也有学者 利用单一生物、理化指标或综合指标对淮河流域或部分河段水质状况评价的结果显示水体处于中-重污染 状态. 赵坤 ${ }^{[37]}$ 利用淮河流域轮虫多样性指数评价水质状况显示, 流域内多数河段处于重污染状态. 袁家辉 等 ${ }^{[20]}$ 利用浮游生物群落结构指标和硅藻指数对颖河 (淮河干流左岸最大的支流) 水质进行评价, 显示颖河 水质处于中度偏重的污染水平, 而且水体的人为有机污染程度在加重. 左其亭等 ${ }^{[38]}$ 运用水生态健康综合指 数法和水体水质综合污染指数对淮河中上游水生态健康状况进行评价, 结果显示水生态退化较严重, $60 \%$ 的 监测断面处于 “亚病态”或 “病态” 水平. 高远等 ${ }^{[19]}$ 研究发现, 山东沂河小流域内的主要河流水质状况为 $\beta$ 中污, 而且河流上橡胶坝的建设改变了水量的时空调配, 降低了河流的流速, 从而使浮游植物群落结构有从 河流型向湖泊型转变的趋势. 淮河流域内多数河流已受到一定程度的污染, 加之流域内闸坝数量较多, 导致 河流自净能力下降, 水质状况不容乐观, 应加强流域内水污染综合治理及其水生态修复工程, 防止水质进一 步恶化.

\section{4 结论}

1) 淮河流域浮游植物种类较丰富, 共鉴定 244 种, 隶属于 8 门 104 属, 以绿藻和硅藻门的种类为主. 浮 游植物生物量平均值为 $3.93 \mathrm{mg} / \mathrm{L}$, 以甲藻门、硅藻门和隐藻门为主, 分别为 $1.03 、 0.92$ 和 $0.77 \mathrm{mg} / \mathrm{L}$, 分别占 总生物量的 $26.09 \% 、 23.36 \%$ 和 $19.50 \%$. 浮游植物种类数和生物量平面分布差异显著, 在上游河道和南部山 区以及江苏省下游河道较低,在中游河道较高.

2) 淮河流域浮游植物优势种以指示水体中营养到富营养状态的种类为主. 主要优势种为隐藻门的啮蚀 隐藻、硅藻门的梅尼小环藻和甲藻门的角甲藻等.

3) 淮河流域浮游植物多样性指数较低, 流域内多数样点处于中-重污染状态,与流域水环境现状和优势 种评价结果相一致, 说明浮游植物可以作为大型流域水质状况的评价指标.

致谢: 感谢南京大学万安博士、万云博士和本实验室赵坤、房勇、任红叶、刘浩等在样品采集过程中给予的无 私帮助.

\section{5 参考文献}

[ 1 ] Meng Shunlong, Chen Jiazhang, Hu Gengdong et al. Phytoplankton community characteristics and its eco-assessment on water quality in Lihu Lake, Taihu Lake. Resources and Environment in the Yangtze Basin, 2010, 19 ( 1) : 30-36. [孟顺 
龙, 陈家长, 胡庚东等. 太湖䔄湖浮游植物群落特征及其对水质的评价. 长江流域资源与环境, 2010, 19(1): 30-36.]

[ 2 ] Borics G, Görgényi J, Grigorszky I et al. The role of phytoplankton diversity metrics in shallow lake and river quality assessment. Ecological Indicators, 2014, 45: 28-36.

[ 3 ] Chen Lijing, Wu Zhuchen, Hu Zhongjun et al. Phytoplankton community structure in Mingzhu Lake of Chongming Island, Shanghai. Chinese Journal of Applied Ecology, 2011, 22(6): 1599-1605. [ 陈立婧, 吴竹臣, 胡忠军等. 上海崇明岛明 珠湖浮游植物群落结构. 应用生态学报, 2011, 22(6): 1599-1605.]

[ 4 ] Wang Jie, Feng Jia, Xie Shulian et al. Phytoplankton diversity and off-flavor-producing Microcystis in the Taiyuan region of the Fenhe River. Acta Ecologica Sinica, 2015, 35(10): 3357-3363. [王捷, 冯佳, 谢树莲等. 汾河太原河段浮游植物 多样性及微囊藻产异味物质研究. 生态学报, 2015, 35(10): 3357-3363.]

[ 5 ] Kofoid CA. The plankton of the Illinois River, 1894-1899: With introductory notes upon the hydrography of the Illinois River and its basin. Gazette Press, 1903.

[ 6 ] Reinhard EG. The plankton ecology of the upper Mississippi, Minneapolis to Winona. Ecological Monographs, 1931, 1 (4) : 396-464.

[ 7 ] Krogmann DW, Butalla R, Sprinkle J. Blooms of cyanobacteria on the Potomac River. Plant Physiology, 1986, 80(3): $667-671$.

[ 8 ] Borics G, Várbíró G, Grigorszky I et al. A new evaluation technique of potamo-plankton for the assessment of the ecological status of rivers. Archiv fir Hydrobiologie, 2007, 17(3/4) : 465-486.

[ 9 ] Reavie ED, Jicha TM, Angradi TR et al. Algal assemblages for large river monitoring comparison among biovolume, absolute and relative abundance metrics. Ecological Indicators, 2010, 10(2) : 167-177.

[10] Sabater S, Artigas J, Dur ANC et al. Longitudinal development of chlorophyll and phytoplankton assemblages in a regulated large river (the Ebro River). Science of the Total Environment, 2008, 404(1) : 196-206.

[11] Wu N, Schmalz B, Fohrer N. Distribution of phytoplankton in a German lowland river in relation to environmental factors. Journal of Plankton Research, 2011, 33(5) : 807-820.

[12] Hong Song, Chen Jingsheng. Structure characteristics of aquatic community from the main rivers in China. Acta Hydrobiologica Sinica, 2002, 26(3) : 295-305. [洪松, 陈静生. 中国河流水生生物群落结构特征探讨. 水生生物学报, $2002,26(3): 295-305$. ]

[13] Wu Bo, Chen Dehui, Wu Qiong et al. Study on the structure of phytoplankton community and water quality monitoring in Huangpu River. Journal of Wuhan Botanical Research, 2007, 25(5): 467-472. [吴波, 陈德辉, 吴琼等. 黄浦江浮游 植物群落结构及其对水环境的指示作用. 武汉植物学研究, 2007, 25(5): 467-472.]

[14] Li Fangfang, Dong Fang, Duan Meng et al. Phytoplankton community structure and water quality of Daliaohe river system in summer. Chinese Journal of Ecology, 2011, 30(11) : 2489-2496. [李芳芳, 董芳, 段梦等. 大辽河水系夏季浮游植 物群落结构特征及水质评价. 生态学杂志, 2011, 30(11) : 2489-2496.]

[15] Wang Shan, Yu Ming, Liu Quanru et al. Phytoplankton species composition and biodiversity in Dongjiang River. Resources Science, 2013, 35(3) : 473-480. [王珊, 于明, 刘全儒等. 东江干流浮游植物的物种组成及多样性分析. 资源科学, $2013,35(3): 473-480$. $]$

[16] Jiang Yuan, Peng Qiuzhi, Liao Jianyu et al. Advances and prospects for research into phytoplankton and river habitats. Resources Science, 2013, 35(3) : 461-472. [ 江源, 彭秋志, 廖剑宇等. 浮游藻类与河流生境关系研究进展与展望. 资 源科学, 2013, 35(3) : 461-472.]

[17] Yi Shaokui, Li Jie, Zeng Cong et al. Horizontal distribution pattern of phytoplankton species richness and composition in the Haihe river basin. Acta Scientiae Circumstantiae, 2013, 33(5): 1467-1474. [易少奎, 黎洁, 曾聪等. 海河流域浮 游植物物种组成与丰富度水平分布格局. 环境科学学报, 2013, 33(5): 1467-1474.]

[18] Li Yaoyao. Research of health evaluation and restoration mode on river ecosystem in Huaihe River Basin (Henan Section) [Dissertation]. Zhengzhou: Zhengzhou University, 2015. [李瑶瑶. 淮河流域 (河南段)河流生态系统健康评价及修复 模式研究 [学位论文]. 郑州: 郑州大学, 2015.]

[19] Gao Yuan, Su Yuxiang, Qi Shucai. Phytoplankton and evaluation of water quality in Yi River watershed. J Lake Sci, 2008, 20(4) : 544-548. DOI: 10.18307/2008.0420. [高远, 苏宇祥, 元树财. 沂河流域浮游植物与水质评价. 湖泊 科学, $2008,20(4): 544-548$. ] 
[20] Yuan Jiahui, Sun Changle. An evaluation of water pollution and studies of the Ying River by means of phytoplankton. Journal of Fuyang Teachers College (Natural Science), 2004, 21(3) : 46-49. [袁家辉, 孙常乐. 浮游植物评价颖河水质污 染研究. 阜阳师范学院学报 (自然科学版), 2004, 21(3) : 46-49.]

[21] Gu Wanlong, Wang Jijun, Zhu Yeyu et al. Annual distribution of precipitation over the Huaihe River Basin. Resources and Environment in the Yangtze Basin, 2010, 19(4): 426-431. [顾万龙, 王纪军, 朱业玉等. 淮河流域降水量年内分配 变化规律分析. 长江流域资源与环境, 2010, 19(4): 426-431.]

[22] Zhang Zongshe, Huang Xiangfei eds. The methods for freshwater plankton research. Beijing: Science Press, 1991. [章宗 涉, 黄祥飞. 淡水浮游生物研究方法. 北京: 科学出版社, 1991.]

[23] Hu Hongjun, Wei Yinxin eds. The freshwater algae of China Systematics, taxonomy and ecology. Beijing: Science Press, 2006. [胡鸿钧, 魏印心. 中国淡水藻类. 北京: 科学出版社, 2006.]

[24] Hillebrand H. Biovolume calculations for pelagic and benthic microalgae. Journal of Phycology, 1999, 35: 403-424.

[25] Kuang Qijun, Hu Zhengyu, Zhou Guangie et al. Investigation on phytoplankton in Xiangxi River Watershed and the evaluation of its water quality. Journal of Wuhan Botanical Research, 2004, 22(6): 507-513. [况琪军, 胡征宇, 周广杰等. 香溪河流域浮游植物调查与水质评价. 武汉植物学研究, 2004, 22(6): 507-513.]

[26] Wang Yue, Xia Shuang, Pei Guofeng. Community structure of phytoplankton in the mainstream of the Yangtze River in Hubei. Journal of Ecology and Rural Environment, 2015, 31(6): 916-922. [王岳, 夏爽, 裴国凤. 长江干流湖北段浮 游藻类群落结构特征. 生态与农村环境学报, 2015, 31(6) : 916-922.]

[27] Liu Zugen, Zhang Zhu, Zhang Meng et al. Classification of functional groups and community structure of phytoplankton in the Ganjiang River. Resources and Environment in the Yangtze Basin, 2012, 21(3): 375-384. [刘足根, 张柱, 张萌等. 赣江流域浮游植物群落结构与功能类群划分. 长江流域资源与环境, 2012, 21(3): 375-384.]

[28] Yuan Yongfeng, Li Yindi, Zhang Linlin et al. Investigation \& research on hydrobios resources in the middle and upper reaches of main Yellow River. Journal of Hydroecology, 2009, 2(6):15-19. [袁永锋, 李引娣, 张林林等. 黄河干流中上 游水生生物资源调查研究. 水生态学杂志. 2009, 2(6) : 15-19.]

[29] Liu Yan. Phytoplankton in Ergis River watershed and the adjacent inland River Basins[Dissertation]. Shanghai: Shanghai Ocean University, 2011. [刘艳. 额尔齐斯河及邻近内陆河流域浮游植物生态学研究 [ 学位论文]. 上海: 上海海洋 大学, 2011.]

[30] Xu Chunyan, Yu Qiujia, Xu Fengjie. Niche analysis of phytoplankton's dominant species in Dianshan Lake of East China. Chinese Journal of Applied Ecology, 2012, 23(9): 2550-2558. [徐春燕, 俞秋佳, 徐凤洁等. 淀山湖浮游植物优势种 生态位. 应用生态学报, 2012, 23(9) : 2550-2558.]

[31] Wu Li, Li Yuanling, Chen Yansong. Characteristics of community structures of zooplankton in the mainstream of Huaihe River. J Lake Sci, 2015, 27 (5) : 932-940. DOI: 10.18307/2015.0521. [ 吴利, 李源玲, 陈延松. 淮河干流浮游动物群 落结构特征. 湖泊科学, 2015, 27 (5): 932-940.]

[32] Reynolds CS, Descy DP, Padisák J. Are phytoplankton dynamics in rivers so different from those in shallow lakes? Hydrobiologia, 1994, 289(1/2/3): 1-7.

[33] Willén E. Planktonic green algae in an acidification gradient of nutrient-poor lakes. Archrive Protistaked, 1992, 141: 47-64.

[34] Reynolds CS, Huszar V, KruK C et al. Towards a functional classification of the freshwater phytoplankton. Journal of Plankton Research, 2002, 24(5): 417-428.

[35] Padisák J, Crossetti LO, Naselli-Flores L. Use and misuse in the application of the phytoplankton functional classification: A critical review with updates. Hydrobiologia, 2009, 621(1) :1-19.

[36] Ning Yuan, Qian Min, Wang Yutai eds. Hydraulic manuals of Huaihe River Basin, Beijing: Science Press, 2003. [宁 远, 钱敏, 王玉太. 淮河流域水利手册. 北京: 科学出版社, 2003.]

[37] Zhao Kun. Distribution pattern of rotifera and correlation to its environmental factors in the Huaihe River Basin[ Dissertation]. Shanghai : Shanghai Normal University, 2014. [赵坤. 淮河流域轮虫分布格局及其与环境因子相关性的研究 [学位论文]. 上海: 上海师范大学, 2014.]

[38] Zuo Qiting, Chen Hao, Zhang Yongyong. Impact factors and health assessment of aquatic ecosystem in upper and middle Huai River Basin. Journal of Hydraulic Engineering, 2015, 46(9) : 1019-1027. [左其亭, 陈豪, 张永勇. 淮河中上游 水生态健康影响因子及其健康评价. 水利学报, 2015, 46(9): 1019-1027.] 